\title{
A NEIMEYER ÉS MOORE-FÉLE MULTIDIMENZIONÁLIS HALÁLFÉLELEM SKÁLA VALIDÁLÁSA MAGYAR POPULÁCIÓN
}

\author{
ZANA ÁGNES* - HEGEDÜS KATALIN - SZABÓ GÁBOR
}

Semmelweis Egyetem, Magatartástudományi Intézet, Budapest

(Beérkezett: 2006. július 22.; elfogadva: 2006. július 28.)

\begin{abstract}
Kutatásunk célja a halálról alkotott elképzelések generációs értékítélet-különbségeinek összehasonlító vizsgálata a magyar társadalomban. A halállal kapcsolatos, leginkább félelmet keltő dimenziók mérésére kérdőíves vizsgálatot végeztünk, 178 fős célpopuláción. A felméréshez a Neimeyer és Moore-féle Multidimenzionális Halálfélelem Skálát (MFODS, 42 tétel, 8 faktorba rendezve) használtuk. A skálát Lester Halál Iránti Attitúd Skálájával, a Rövidített Beck Depresszió Kérdôívvel és a STAI-T skálával validáltuk és bemértük. A statisztikai elemzés alapján a skála valid, jól mér a magyar populáción, a skálák egymással jól korrelálnak. Az MFODS eredeti faktorstruktúrája kirajzolódott a magyar mintán, az 5. faktor kivételével. A kapott eredmények - mint a fiatalok és a nók magasabb halálfélelme és szorongása - alátámasztják a szakirodalomban korábban közölt kutatási eredményeket.
\end{abstract}

Kulcsszavak: halál, halálfélelem, halálattitúd, szorongás, transzcendencia, tanatológia, pszichológia, multidimenzionális halálfélelem skála, validitás, reliabilitás

Tanulmányunk témája a halálkép változásának generációs összehasonlító vizsgálata. A kutatás célja a halálról alkotott elképzelések, attitűdök, a leginkább félelmet keltó komponensek vizsgálata a különbözó korosztályok és társadalmi csoportok tekintetében. Annak felderítésében, hogy a ma embere mit gondol a halálról, és milyen a transzcendenshez való viszonya, a társadalomtudományi, kvalitatív kutatások mellett a pszichometriai méróeszközök használata is egyre nagyobb teret kap, ezért azt a kérdést, hogy melyek a halálfélelemre vonatkozó, leginkább félelmet kel-

* Levelező szerző: Zana Ágnes, Semmelweis Egyetem, Magatartástudományi Intézet, 1089 Budapest, Nagyvárad tér 4. E-mail: zanagi@net.sote.hu 
tô faktorok, célszerúnek látszott kérdőíves vizsgálattal megközelíteni. Mivel a halálattitúd transzcendens dimenzióira is kíváncsiak voltunk, megfelelóen árnyalt, többdimenziós skálát kerestünk.

A tervezett kérơíves felméréshez egy halálfélelem-, illetve egy halálattitúd-skálát használtunk: a Neimeyer és Moore-féle Multidimenzionális Halálfélelem Skálát (Multidimensional Fear of Death Scale) és Lester Halál Iránti Attitúd Skáláját (Lester Attitude Toward Death Scale) (Lester 1991), melyeket a hivatalos validálási folyamat (Rózsa és mtsai 2003) keretében bemértünk.

Azt, hogy mit jelent maga a halálfélelem, az 1950-es évektól az 1980as évekig az empirikus kutatásokban a haláltól való szorongással azonosították, és ez alapján mérték (Neimeyer és mtsai 2004). A tipikus halálszorongás kérdő́ivek egyszerú felépítésủek voltak, és a halállal kapcsolatos szorongások egyes területeire koncentráltak, fó irányvonaluk a halállal kapcsolatos tapasztalatok indukálta szorongások mérése volt, mint például a félelem a fájdalmas haláltól (szenvedéssel teli haldoklástól), vagy a test integritásának elvesztése felett érzett félelem. A korai méréseket a korrekt, statisztikai szempontból történó bemérés hiánya jellemezte. A pontos mérést a szakirodalom megfeleló ismerete mellett az okok, összefüggések és a halállal kapcsolatos negatív attitúdök feltárása segíti (Kastenbaum és Costa 1977).

Hoelter 1979-ben publikálta az általa kidolgozott skálát (MFODS Multidimensional Fear of Death Scale) (Hoelter 1979), amely emocionális reakciók és szubjektív érzések formáit kutatta a halálfélelemmel kapcsolatban. Ez a skála multidimenzionális volt, 42 tételból állt, és nyolc alskálát tartalmazott, melyek a halálfélelem különböző területeire kérdeztek rá. A késóbbi, Neimeyer-féle változattal szemben Hoelter csupán faktoranalízist alkalmazott az eredeti skála hitelesítése folyamán. A továbbiakban a kutatók Hoelter skáláját jól alkalmazható, kifinomult mérôeszköznek találták a halálfélelem mérésére vonatkozóan.

Hoelter a kutatás kezdeti szakaszában próbatesztet töltetett ki 143 férfi és 232 nó fóiskolai hallgatóval, s ennek alapján állította fel a faktorstruktúrát. Walkey 1982-ben felvette a skálát 256 új-zélandi diákkal és családjukkal, de a faktorok csak részben rajzolódtak ki, egyes kérdések kiestek (Walkey 1982). 1985-86-ban, az arab verzió bemérésekor 84, az Egyesült Államokban éló szaúdi férfin vették fel a kérdóívet, de az eredeti faktorstruktúrát nem sikerült reprodukálni (Long 1986). A kudarcot az iszlám és a nyugati, keresztény kultúrák közötti jelentős különbségekkel magyarázták, tehát valószínúsíthető, hogy a skála a nyugati típusú, keresztény társadalmakban mér jól, de az eltérések megítéléséhez jelentôs adalék, hogy az elsó két felmérés fóleg fóiskolai hallgatókkal történt. 
Roff és munkatársai 2002-ben publikálták a skála litván verziójának validálási tapasztalatait. A kutatás célja a halál-szorongás és a vallásosság összefüggéseinek vizsgálata volt. A célpopuláció $(N=130)$ vegyes korcsoportú volt, fóleg egészségügyi dolgozókból és hallgatókból állt A skála jól mér a litván populáción, de a hatos, hetes faktorok nem jól korreláltak, egyes tételek kiestek.

Az MFODS skáláról a magyar szakirodalomban Kulcsár Zsuzsanna írt elóször (Kulcsár 1998), a tanatopszichológiai irodalomban publikált halálattitúd-skálák ismertetésében, azzal a megjegyzéssel, hogy ez az eddig legkidolgozottabb halálfélelem-skála. Bár a szerző a skálát Neimeyer és Moore Multidimenzionális halálfélelem-skálájának nevezi, az eredeti szerzó Hoelter. Neimeyer és Moore nevéhez a skála pszichometriai szempontból történố korrekciója és validálása fúződik. Az angol nyelvú szakirodalom - köztük Neimeyer és Moore is - a skála eredeti elnevezését használja (MFODS, Neimeyer és Moore 1994), de mivel a szerzók a validálás során kisebb változtatásokat eszközöltek a faktorstruktúrán és a tételeken, ezért a magyar változatnak a Neimeyer és Moore féle Multidimenzionális Halálfélelem Skála elnevezést adtuk (rövidített formában továbbra is MFODS).

Neimeyer és Moore célja az MFODS skálával kapcsolatos pszichometriai tulajdonságok leírásának teljes irodalmi áttekintése és összegzése volt, különös tekintettel a faktorstruktúrára, amennyiben ez kiemeli a skála legjellemzóbb sajátosságait, továbbá megvizsgálni a skála validitását és relibialitását, valamint a skála különböző dimenzióiban a viszonyulás és magatartás korrelátumait. Kutatási eredményeiket egy 1994-ben megjelent tanulmányban publikálták (Neimeyer és Moore 1994).

A faktorstruktúra letisztítása után Neimeyer és munkatársai a kérdőívet felvették 145 nôvérhallgatón és egy 130 fős kontrollcsoporton. További finomítások után Neimeyer felvette a kérdôívet 504 fóiskolai hallgatón (a kutatás célja kifejezetten a halálról alkotott személyes elképzelések vizsgálata volt).

További kutatások után felmerült a szerzókben az az igény, hogy a skálát kipróbálják vegyes korcsoporton, céljuk a skála korosztálytól független használhatósága volt. Mivel a skála eddig egy viszonylag kis réteget, és speciális korosztályt célzott meg, Neimeyer és munkatársai egy átfogó, nagy kutatást végeztek, melynek során különböző végzettségú, korú és társadalmi osztályba tartozó emberekkel vették föl a skálát. A 952 fős felmérés alapján végezték el a skála validálását. 


\section{MÓDSZER}

Az MFODS skála bemérését 178 fốn végeztük. A célpopulációt három alcsoportra osztottuk: középiskolások és medikusok (fiatal csoport, $\mathrm{N}=$ 118, átlagéletkor 18 év), aktív egészségügyi dolgozók (felnôtt csoport, $\mathrm{N}=$ 38 , átlagéletkor 35 év), és az 55 éven felüliek (idôs csoport, $\mathrm{N}=22$, átlagéletkor 66 év). A nemek szerinti eloszlást tekintve: a vizsgálatban 120 nó és 56 férfi vett részt. A reliabilitás és a validitás vizsgálata szempontjából a szakirodalmi tapasztalat alapján jónak láttuk a csoportokat összevontan vizsgálni. A korosztályos meghatározás a kutatás komparatív szakaszában kap jelentôséget.

Az MFODS skála 42 tételból áll, nyolc faktorba rendezve. A faktorok a hozzájuk tartozó tételekkel a következók (a csillaggal jelölt tételeket fordítottan pontozzák):

1. félelem a meghalás folyamatától (beleértve a fájdalmas és erôszakos halált) 1, 13, 22, 27, 31, 42;

2. félelem a halottól (az emberi és állati tetemtól való félelmet egyaránt jelzi) 2, 14*, 23, 26, 32, 39;

3. félelem a megsemmisüléstól (beleértve a test oszlását vagy elégetését) $3^{*}, 15,24,33$;

4. jelentôs társak féltése (a számunkra fontos személyek halálától való félelem és a hozzátartozóink ránk irányuló aggodalma egyaránt beletartozik) 4, 16, 17, 25*, 34, 37;

5. félelem az ismeretlentól (félelem a létezés megszúnésétól és a halál utáni élettól vagy annak hiányától) 5, 9*, 18, 30, 36;

6. félelem a halál tudatos átélésétól (szorongás attól, hogy valakit tévesen holttá nyilvánítanak, bár még él) 6, 10, 19, 29, 38;

7. a test féltése a halál után (félelem a test bomlásától és izolációjától), $7,11,20,28^{*}, 35,40$;

8. félelem a korai haláltól (miszerint nem érjük el kitưzött céljainkat, nem valósíthatjuk meg vágyainkat) 8, 12, 21, 41.

A skála széles spektrumú, a faktorok a halálfélelem különböző területeit érintik. Az egyes alskálák a racionális tartományon túl a halálfélelem illetve -attitúd transzcendens, spirituális dimenzióit is vizsgálni kívánja (pl. 5. faktor). A válaszok 1-5 skálán, az egyetértés mértéke szerint adhatók ( 1 = teljesen egyetértek, 5 = egyáltalán nem értek egyet). Érdekessége, hogy fordítva mér, tehát az alacsonyabb érték magasabb halálfélelmet jelöl. A jobb érthetőség és ábrázolhatóság kedvéért az értékek fordítottjával dolgozunk, tehát a magasabb értékek magasabb félelmet jeleznek. 
(A Lester-skála dichotóm, 21 tételból áll, minden itemhez eltérố nagyságú skálaértékek tartoznak, a halálról alkotott elképzelések spirituálisabb, emocionálisabb struktúráit vizsgálja.)

A szerzóktól engedélyt kaptunk a skálák használatára. Ezután az elóírásoknak megfelelően három különbözó fordítás készült a skáláról, majd az egyeztetés után visszafordítottuk az eredeti (angol) nyelvre. Miután egy lektor összevetette a fordítást az eredeti szöveggel, elkészült a végleges változat. Szabályosan már valid halálfélelem-, illetve halálszorongásskálával kellett volna a két skálát bemérni. Mivel azonban Magyarországon validált halálfélelem-, illetve halálattitúd-skálát nem találtunk, az MFODS-t a Rövidített Beck Depresszió Kérdőívvel (9 tétel) és a STAI-T skálával (20 tétel) validáltuk.

A statisztikai elemzés során megvizsgáltuk az MFODS pszichometriai jellemzóit, ennek keretében az egyszerú leíró statisztikák (átlag, szórás) mellett kiszámítottuk a skálák megbízhatóságát, belső konzisztenciáját becslő Cronbach-alfa mutatókat. Az összes lehetséges tesztfelezéssel elóálló átlagkorrelációkat mutató Cronbach-alfa értékeket 0,60 fölött elfogadhatónak tekinthetjük, míg az alacsonyabb értékek a skálát alkotó tételek heterogenitását jelzik. A faktor extrakciót követóen Varimax rotációs eljárással vizsgáltuk az egyes alskálák elrendeződését. A csoportok közötti (kor, nem) skálaátlagok összevetésében kétmintás t-próbát alkalmaztunk.

Az elemzéseket az SPSS 10.0 statisztikai programcsomaggal végeztük.

\section{EREDMÉNYEK}

Összesítve a skálák egy irányba mérnek, a Pearson-féle korrelációk szerint szorosan együttjárnak, a reliabilitás vizsgálat során jó Cronbach-alfa értékeket kaptunk. Tekintetbe véve, hogy az MFODS összpontszám normális eloszlású, de maguk a faktorok nem, ezért a faktoroknál a Pearsonféle korreláció helyett annak robusztus próbáit, a Kendall-tau-t és a Speaman-féle rangkorrelációt használtuk, Mindezek alapján a dimenziók együttjárása megfeleló. Faktoranalízissel ellenóriztük az irodalomban közölt faktorstruktúrát. Az MFODS skála faktorainak Cronbach-alfái a következók: 1) 0,76; 2) 0,74; 3) 0,60;4) 0,71; 5) 0,45; 6) 0,58; 7) 0,72; 8) 0,76. A teljes skála Cronbach-alfája: 0,91.

Az MFODS skála 8 faktorából hét elfogadható Cronbach-alfa értéket adott, az ötödik faktor kivételével. A hatodik faktort az alacsony belsó konzisztenciája ellenére, a dimenziót alkotó alacsony tételszám és az elfogadható item-totál korrelációk miatt elfogadhatónak tartjuk (1. táblázat). 
1. táblázat. A hatodik faktor item-totál és item-maradék korrelációi

\begin{tabular}{|c|c|c|c|}
\hline & Tételek & $\begin{array}{c}\text { Item- } \\
\text { maradék } \\
\text { korreláció }\end{array}$ & $\begin{array}{l}\text { Item-totál } \\
\text { korreláció }\end{array}$ \\
\hline \multicolumn{4}{|l|}{ 6. faktor } \\
\hline 1. NM6 & $\begin{array}{l}\text { Valószínú, hogy sokakat halottá nyilvánítanak, } \\
\text { bár még élnek. }\end{array}$ & 0,28 & 0,54 \\
\hline 2. NM10 & Félek, hogy élve temetnek el. & 0,42 & 0,70 \\
\hline 3. NM19 & $\begin{array}{l}\text { Minden esetben boncolást kellene végezni, hogy } \\
\text { megbizonyosodjanak a halál beálltáról. }\end{array}$ & 0,26 & 0,51 \\
\hline & $\begin{array}{l}\text { Iszonyattal tölt el, ha arra gondolok, hogy eszméle- } \\
\text { temnél vagyok, miközben a halottasházban fekszem. }\end{array}$ & 0,36 & 0,64 \\
\hline 5. NM38 & $\begin{array}{l}\text { Remélem, több orvos is megvizsgál majd, mielótt } \\
\text { holttá nyilvánítanak. }\end{array}$ & 0,38 & 0,65 \\
\hline
\end{tabular}

Érdekes módon minden vizsgált csoportnál a három legerôsebb félelmet keltő faktor a Jelentôs társak féltése, a Félelem a meghalás folyamatától és a Félelem a halottól (a litván kutatásban szintén az 1. és a 4. faktor jelezte a legmagasabb félelmet). A fiatal és a felnótt korcsoport eredményei között szignifikáns eltérést nem tapasztaltunk, a legjellemzóbb különbség a fiatal és az idôs korcsoport között van, de nem a félelem dimenzióiban, hanem a félelem mértékében. Míg az idôs csoportban a Jelentốs társak féltése volt a legerôsebb, a fiatal csoportban a Félelem a meghalás folyama-

2. táblázat. Eredmények összegzése a két, szignifikáns eltérést mutató korcsoport esetében

\begin{tabular}{|c|c|c|c|c|}
\hline \multirow[t]{2}{*}{ Skálák és az MFODS skála faktorai } & \multicolumn{2}{|c|}{ Értékátlagok } & \multirow{2}{*}{$\frac{\text { F-test }}{\text { sign }}$} & $\mathrm{d} / \mathrm{t}$-test \\
\hline & $\begin{array}{c}\text { Fiatal } \\
\text { csoport } \\
(\mathrm{N}=118)\end{array}$ & $\begin{array}{c}\text { Idôs } \\
\text { csoport } \\
(\mathrm{N}=22)\end{array}$ & & sign \\
\hline 1. Félelem a meghalás folyamatától & 20,7 & 17,2 & 0,409 & 0,018 \\
\hline 2. Félelem a halottól & 18,2 & 13,9 & 0,009 & 0,000 \\
\hline 3. Félelem a megsemmisüléstól & 13,3 & 7,9 & 0,020 & 0,000 \\
\hline 4. Jelentôs társak féltése & 25,3 & 22,7 & 0,133 & 0,018 \\
\hline 5. Félelem az ismeretlentôl & 15,8 & 14,4 & 0,751 & 0,106 \\
\hline 6. Félelem a halál tudatos átélésétól & 13,4 & 9,4 & 0,615 & 0,001 \\
\hline 7. A test féltése a halál után & 13,7 & 10,1 & 0,036 & 0,001 \\
\hline 8. Félelem a korai haláltól & 12,9 & 8,6 & 0,384 & 0,000 \\
\hline Összesített halálfélelem (42-210) & 133,3 & 104,0 & 0,036 & 0,000 \\
\hline Lester Skála (0-131.78) & 69,0 & 67,9 & 0,769 & 0,831 \\
\hline Vonásszorongás (20-80) & 42,3 & 39,4 & 0,266 & 0,215 \\
\hline Depresszió (0-63) & 10,2 & 5,0 & 0,065 & 0,015 \\
\hline
\end{tabular}


3. táblázat. Skála-főösszegek nemek szerinti leírása

\begin{tabular}{|l|c|c|c|}
\hline & Férfi & Nő & Szign. \\
\hline $\mathrm{N}$ & 56 & 120 & \\
\hline Lester Halálfélelem Skála (0-131.78) & 65,1 & 69,9 & 0,188 \\
\hline MFODS összesített halálfélelem & 131,8 & 123,4 & 0,061 \\
\hline Vonásszorongás & 39,3 & 42,5 & 0,045 \\
\hline Beck Depresszió Skála (0-63) & 8,75 & 8,76 & 0,996 \\
\hline
\end{tabular}

tától faktor (1. táblázat). A kapott értékek összevetéséból mind az MFODS, mind a Lester-skálánál szignifikáns eredményeket kaptunk, amelyek alátámasztják a szakirodalomban közölt tendenciákat (Cicirelli 2001; Hegedús és mtsai 2001), így a fiatal korcsoport szignifikánsan magasabb halálfélelmét, nemek közötti összehasonlításban pedig a nók magasabb halálfélelmét. Figyelemkeltó eredmény BDI által mért szignifikánsan magas depresszió a fiatal korcsoportban (2. és 3. táblázat).

\section{ÖSSZEFOGLALÁS}

Az eddigi tapasztalatok szerint az MFODS skála magyar változata valid, megfelelóen mér, az összesített halálfélelem-értékek használhatóak a magyar populáción alkalmazott vizsgálatokban. Az eredeti faktorstruktúrából az ötödik faktort (Félelem az ismeretlentól) alkotó tételek különböznek, a tételek nem homogének, tehát nem a dimenzió megbízhatósága kérdéses. Ezt figyelembe kell venni a késóbbi kutatások során, mert felmerül annak a megoldásnak a lehetôsége, hogy a faktort kihagyjuk a mérésból. Ez az eredmény azért is érdekes, mert részben ez a faktor irányul a transzcendens dimenzióra. Úgy túnik, hogy ez a megközelítés nem interpretálható ilyen formában a magyar kultúrkörben.

\section{MELLÉKLET}

\section{Multidimenzionális Halálfélelem Skála}

Kérjük, jelölje meg, hogy mennyire ért egyet az alábbi állításokkal!

( 1 = teljesen egyetértek; 5 = egyáltalán nem értek egyet)

1. Félek a lassú haláltól.

$\begin{array}{lllll}1 & 2 & 3 & 4 & 5\end{array}$

2. Rettegek a ravatalozótól.

$1 \quad 2 \quad 3 \quad 4 \quad 5$

3. Szívesen felajánlanám a holttestemet tudományos célra. 
4. Félek a családtagjaim haldoklásától.

5. Félek, hogy nincs túlvilág.

6. Valószínú, hogy sokakat halottá nyilvánítanak, bár még élnek.

7. Félek, hogy a testem eltorzul, amikor meghalok.

8. Félek, hogy nem érem el kitûzött céljaimat, mielôtt meghalok.

9. Félek, hogy találkozom a Teremtômmel.

10. Félek, hogy élve temetnek el.

11. Rettegek a gondolattól, hogy holttestemet egyszer bebalzsamozzák.

12. Félek, nem fogok olyan sokáig élni, hogy élvezhessem nyugdíjas éveimet.

13. Félek, hogy túzben halok meg.

14. Nem zavarna, ha meg kellene érintenem egy holttestet.

15. Nem akarom, hogy orvostanhallgatók tanulmányozzák a testemet, miután meghalok.

16. Ha szeretteim közül valaki hirtelen halna meg, nagyon sokáig szenvednék.

17. Ha holnap meghalnék, a családom hosszú ideig nem tudna megnyugodni.

18. Félek, hogy a halál létezésünk végét jelenti.

19. Minden esetben boncolást kellene végezni, hogy megbizonyosodjanak a halál beálltáról.

20. Félelemmel tölt el a gondolat, hogy egyszer holtan találnak.

21. Félek, nem lesz elég időm, hogy mindazt megtapasztaljam, amit szeretnék.

22. Félek, hogy nagyon sok fájdalmat fogok érezni a haldoklás során.

23. Holttestet találni szörnyú élmény lehet.

24. Nem szívesen foglalkozom a hamvasztás gondolatával.

25. Egyszer mindenkinek meg kell halnia, ezért nem dúlna föl barátaim halála.

26. Félnék, ha éjjel, egyedül, temetóben kellene sétálnom.

27. Félek attól, hogy rákban fogok meghalni.

28. Nem számít, hogy koporsóban vagy kriptában temetnek el.

29. Iszonyattal tölt el, ha arra gondolok, hogy eszméletemnél vagyok,miközben a halottasházban fekszem.

30. Félek, hogy nincs Isten.

31. Félek a fulladástól (és a vízbefúlástól).

32. Zavarna, ha egy állattetemet kellene eltávolítanom az útról.

33. A szememet nem ajánlanám fel szervátültetésre halálom után.

34. Olykor felzaklat, ha egy ismerósöm meghal.

35. Rémülettel tölt el a gondolat, hogy halálom után be leszek zárva egy koporsóba.

36. Senki sem tudja megmondani biztosan, hogy mi fog történni a halál után. 
37. Ha meghalnék, a barátaim sokáig zaklatottak lennének.

38. Remélem, több orvos is megvizsgál majd, mielőtt holttá nyilvánítanak.

$\begin{array}{lllll}1 & 2 & 3 & 4 & 5\end{array}$

39. Félek mindentól, ami halott.

$\begin{array}{lllll}1 & 2 & 3 & 4 & 5\end{array}$

40. Elrémít a gondolat, hogy halálom után a testem felbomlik.

$\begin{array}{lllll}1 & 2 & 3 & 4 & 5\end{array}$

41. Félek, hogy sosem láthatom a gyermekeimet felnôni.

$\begin{array}{lllll}1 & 2 & 3 & 4 & 5\end{array}$

42. Félek az erőszakos haláltól.

\section{IRODALOM}

Cicirelli, V. G. (2001): Personal meanings of death in older adults and young adults in relation to their fears of death. Death Studies, 25 (8): 663-683.

Hegedús K., Pilling J., Kolosai N., Bognár T. (2001): Ápolók és medikusok halállal és haldoklással kapcsolatos attitúdje. Lege Artis Medicinae, 11 (6-7): 492-499.

Hoelter, J. W. (1979): Multidimensional treatment of fear of death. Journal of Consulting and Clinical Psychology, 47 (5): 996-999.

Kastenbaum, R., Costa, P. (1977): Psychological perspectives on death. American Review of Psychology, 28: 225-249.

Kulcsár Zs. (1998): Egészségpszichológia. ELTE Eötvös Kiadó, Budapest, 140.

Lester, D. (1991): The Lester Attitude Toward Death Scale. Omega, 23 (1): 67-75.

Long, D. D. (1986): A cross-cultural examination of fears of death among Saudi Arabians. Omega, 16 (1): 43-50.

Neimeyer, R. A., Moore, M. K. (1994): Validity and reliability of the Multidimensional Fear of Death Scale. In: Neimeyer, R. A. (ed.): Death Anxiety Handbook. Research, Instrumentation, and Application. Taylor and Francis, Washington, 61-102.

Neimeyer, R. A., Wittkowski, J., Moser, R. P. (2004): Psychological research on death attitudes: an overview and evaluation. Death Studies, 28 (4): 309-340.

Roff, L. L., Butkeviciene, R., Klemmack, D. L. (2002): Death anxiety and religiosity among Lithuanian health and social service professionals. Death Studies, 26 (9): 731-742,

Rózsa S., Réthelyi J., Stauder A., Susánszky É., Mészáros E., Skrabski Á., Kopp M. (2003:) A Hungarostudy 2002 országos reprezentatív felmérés általános módszertana és a felhasznált tesztbattéria pszichometriai jellemzói. Psychiatria Hungarica, 18 (2): 83-94.

Walkey, F. H. (1982): The Multidimensional Fear of Death Scale: an independent analysis. Journal of Consulting and Clinical Psychology, 50: 466-467.

A tanulmány elkészitését segitô támogatások. A tanulmány az OTKA TS-049785 és az NKFP 1b/020/2004 pályázatok támogatásával készült. 
ZANA, ÁGNES - HEGEDÚS, KATALIN - SZABÓ, GÁBOR

\section{VALIDITY AND RELIABILITY OF MULTIDIMENSIONAL FEAR OF DEATH SCALE IN HUNGARIAN POPULATION}

The goal of our research is the examination of generational value - judgment about meaning of death in the Hungarian society. To measure the biggest fear and most important dimensions in fear of death we administered a 178 sample of target population. We used the Multidimensional Fear of Death Scale (MFODS, 42 items, 8 factors). We validated the MFODS with Lester Attitude toward Death Scale, shortened BDI and STAI-T Scale. Based on the result of measures the MFODS is valid in the Hungarian population, the scales have good correlation with one another. The original factor structure has been drawn in the Hungarian sample well except for the $5^{\text {th }}$ factor. Results - for instance higher fear of death and anxiety by women - are the same as in earlier professional studies.

Keywords: death, fear of death, death attitudes, anxiety, transcendence, religiosity, thanatology, psychology, Multidimensional Fear of Death Scale, validity, reliability 